\title{
Diet composition of the otter Lutra lutra in the Bieszczady Mountains, south-east Poland
}

\author{
Grzegorz HARNA
}

\begin{abstract}
Harna G. 1993. Diet composition of the otter Lutra lutra in the Bieszczady Mountains, south-east Poland. Acta theriol. 38: 167 - 174 .

The diet of the otter Lutra lutra (Linnaeus, 1758) was studied in the Bieszczady Mts (south-east Poland), at four locations situated on the small rivers from October 1987 to June 1989. In all, 379 samples of spraints were analysed and 1687 animals preyed upon belonging to various systematic groups were identified. Frequency analysis indicated that most of the prey was fish $(63.4 \%)$ with insects contributing $20.2 \%$ and amphibians $14.5 \%$. Among fish the most frequently occurring were Phoxinus phoxinus (frequency - $15.0 \%$ ), Cottus $\mathrm{sp} .(14.4 \%)$ and Noemacheilus barbatulus $(9.0 \%)$. Relatively low frequencies were found for Salmo trutta $(5.7 \%)$ and Thymallus thymallus $(3.1 \%)$. Percentage analysis indicated that most of the diet comprised fishes (73.2\% of biomass) and much less amphibians (26.8\%). Among fish species S. trutta dominated $(42.4 \%$ of all biomass) over Cottus sp. (10.2\%) and N. barbatulus $(3.9 \%)$.

Institute of Environmental Biology, Jagiellonian University, Ingardena 6, 30-060 Krak6w, Poland

Key words: Lutra lutra, diet, Bieszczady Mts, Poland
\end{abstract}

\section{Introduction}

With a relatively large population of otters, the Bieszczady Mountains are a stronghold for the species in Poland (Pielowski 1980, Sikora 1984). There are many favourable factors contributing to their status, e.g. little human disturbance, an abundance of unpolluted water courses, and an abundant food supply.

The aims of this study were to identify the frequency of prey species found and percentage composition of otter diet. Earlier reports on the subject highlighted frequency mainly, which by itself gives little information about the actual role of particular diet components. There may be great differences between the two estimates (Libois et al. 1987). That is why the percentage estimates have been attempted in this study, despite considerable technical difficulties.

\section{Study area, material and methods}

The assessment of otter diet was based on spraints analysis. Samples were collected between September 1987 and June 1989 within the Bieszczady Mts at four permanent sites: the Osławica river bank near Komańcza village $\left(49^{\circ} 21^{\prime} \mathrm{N}, 2^{\circ} 04^{\prime} \mathrm{E}\right)$, the Osława river bank close to Prełuki village $\left(49^{\circ} 19^{\prime} \mathrm{N}, 22^{\circ} 07^{\prime} \mathrm{E}\right)$, the Solinka river bank between Dołżyca and Buk $\left(49^{\circ} 14^{\prime} \mathrm{N}, 22^{\circ} 22^{\prime} \mathrm{E}\right)$, and the 
Wetlinka stream close to Kalnica village $\left(49^{\circ} 13^{\prime} \mathrm{N}, 22^{\circ} 26^{\prime} \mathrm{E}\right)$. The sites were chosen on the basis of earlier observations, indicating a permanent otter presence in the area. Ecological conditions (water course characteristics, bank vegetation) at all the sites were similar. All were small mountain rivers of fast current, with narrow stony beaches bordered by typical wet meadow vegetation. The aim was to collect 10 samples of spraints at each site monthly. However, under unfavourable conditions (torrential rains, rapid rise of water, abundant snowfall) not enough samples were found, and in certain cases collection had to be abandoned for some time.

The procedure of sample processing was identical to that described by Webb (1976). The spraints were stored dry, then soaked in water with washing powder for several hours prior to analysis, then washed trough a $0.5 \mathrm{~mm}$ sieve with running water. The remnants on the sieve were dried and examined under a dissecting microscope.

Cyprinid fishes, e.g. the minnows Phoxinus phoxinus, were identified mainly from pharyngeal teeth structure (Horoszewicz 1960), the stone loach Noemacheilus barbatulus by characteristic features of bones of the operculum (Hallet-Libois 1984), the sculpin Cottus sp. by bones of the operculum (Webb 1976, Libois et al. 1987), and the perch Perca fluviatilis and the grayling Thymallus thymallus mainly by identifying scales (Webb 1976, Goryczko 1986). The trout Salmo trutta was identified by the characteristic structure of vertebrae (Webb 1976, Camby et al. 1984), or mandible (Hallet-Libois 1984). At the same time fish skeleton fragments were measured with a calibrated ocular to the nearest $0.1 \mathrm{~mm}$ to estimate the size of prey eaten.

Amphibians were also identified by examining skeletal parts - ileum and frontoparietale (Webb 1976, Günther 1985). They were not measured, however, because of the lack of any standards for estimating the size. Mammals were identified by fur fragments, teeth, or skull bone fragments (Kowalski et al. 1984). Insects, crustaceans, and arachnids were identified by the remnants of them chitinous external skeletons.

The frequency assessment of animals occurring in spraint always assumed the lowest possible number for a given category. For example, if the left and right pharyngeal teeth of similar size belonging to the same species of fish was found in a sample, it was counted as only one individual.

The estimate of biomass percentage was performed by approximation compiling various methods described in the literature. The body mass in the minnow, stone loach, sculpin, and trout was estimated on the basis of the relationship between the sizes of the characteristic parts of skeleton and the mass and the length of the whole body (Wise 1980, Hallet-Libois 1984, Libois et al. 1987). In the case of the bleak, gudgeon, and dace length estimates were the only accurate ones available (Hroszewicz 1960, Mann and Beaumont 1980); body mass was estimated applying average data on weight reported by Rolik and Rembiszewski (1987) for the relevant size classes of these fish species.

Since no methods to assess body mass in the asp and barbel were available, both species were included in the Cyprinidae category (not identified by species) and the mass was assumed to be equal to the average mass among the remaining cyprinids (the bleak, gudgeon, dace, and minnow). Similarly the perch and grayling were included among the fishes not identified by species, and the average body mass for all the remaining fish species was used. The body masses in amphibians were estimated from the literature, adopting $20 \mathrm{~g}$ as mass for Rana sp. after Libois et al. (1987), and $7 \mathrm{~g}$ for Bombina variegata, calculated on the basis of data reported by Juszczyk (1974). The body mass for the amphibians not identified by species was estimated as the average for the species identified. The remaining categories of prey (insects, crustaceans, mammals) were not included because of both a lack of methods for mass assessment and their negligible contribution to the otter diet.

\section{Results}

In all, 379 samples of spraints were analysed and 1687 individuals of various animals eaten by otter were identified. The number of samples collected in various seasons at the four sites are given in Table 1. The majority of otter spraints was found in autumn and winter, and the least number in summer. 
Table 1. Number of otter spraints colected and analyzed from the four sites of study area.

\begin{tabular}{lccccc}
\hline & Osławica & Osława & Solinka & Wetlinka & Total \\
\hline Winter & 26 & 26 & 20 & 16 & 89 \\
Spring & 20 & 19 & 14 & 25 & 78 \\
Summer & 17 & 4 & 10 & 11 & 42 \\
Autumn & 42 & 39 & 47 & 42 & 170 \\
Total & 106 & 88 & 91 & 94 & 379 \\
\hline
\end{tabular}

The frequency estimates of prey categories indicate that in the otter diet dominated fish species, followed by insects, amphibians, crustaceans and the remaining categories. The details are given in Table 2 . The statistical significance of seasonal differences between frequencies of main prey categories were assessed by the $\chi^{2}$-test. Significant differences $(\mathrm{df}=3, p<0.001)$ were found, among others, in fishes $\left(\chi^{2}=18.017\right)$, amphibians $\left(\chi^{2}=49.929\right)$, and insects $\left(\chi^{2}=20.987\right)$. The lowest frequency of fish species was found in spring samples, more in summer and autumn samples, and the highest in winter (Fig. 1). Insects were most frequent in summer and least in winter.

The highest frequency of amphibians occurred in spring samples, less in winter, even less in autumn, with very few in summer samples. It should be noted, however, that all the individuals identified to species in summer samples belonged to Bombina variegata, while all those identified in the remaining seasons were exclusively the common frogs Rana temporaria. Seasonal analysis of other categories of prey could not be carried out because of the low frequencies of remains found in spraints.

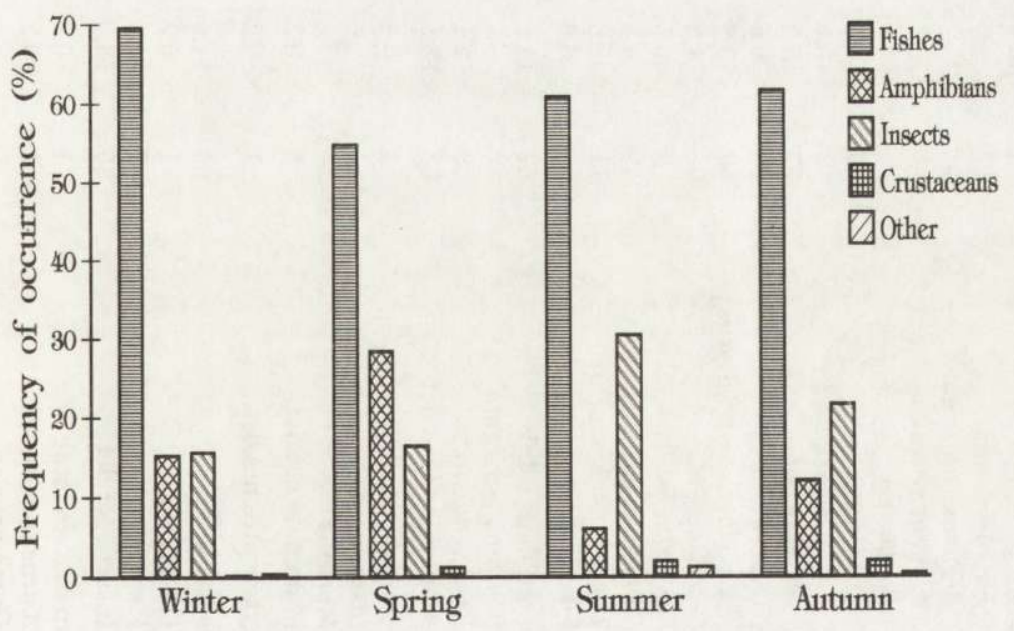

Fig. 1. Seasonal occurrences of important prey caregories of the otter. 


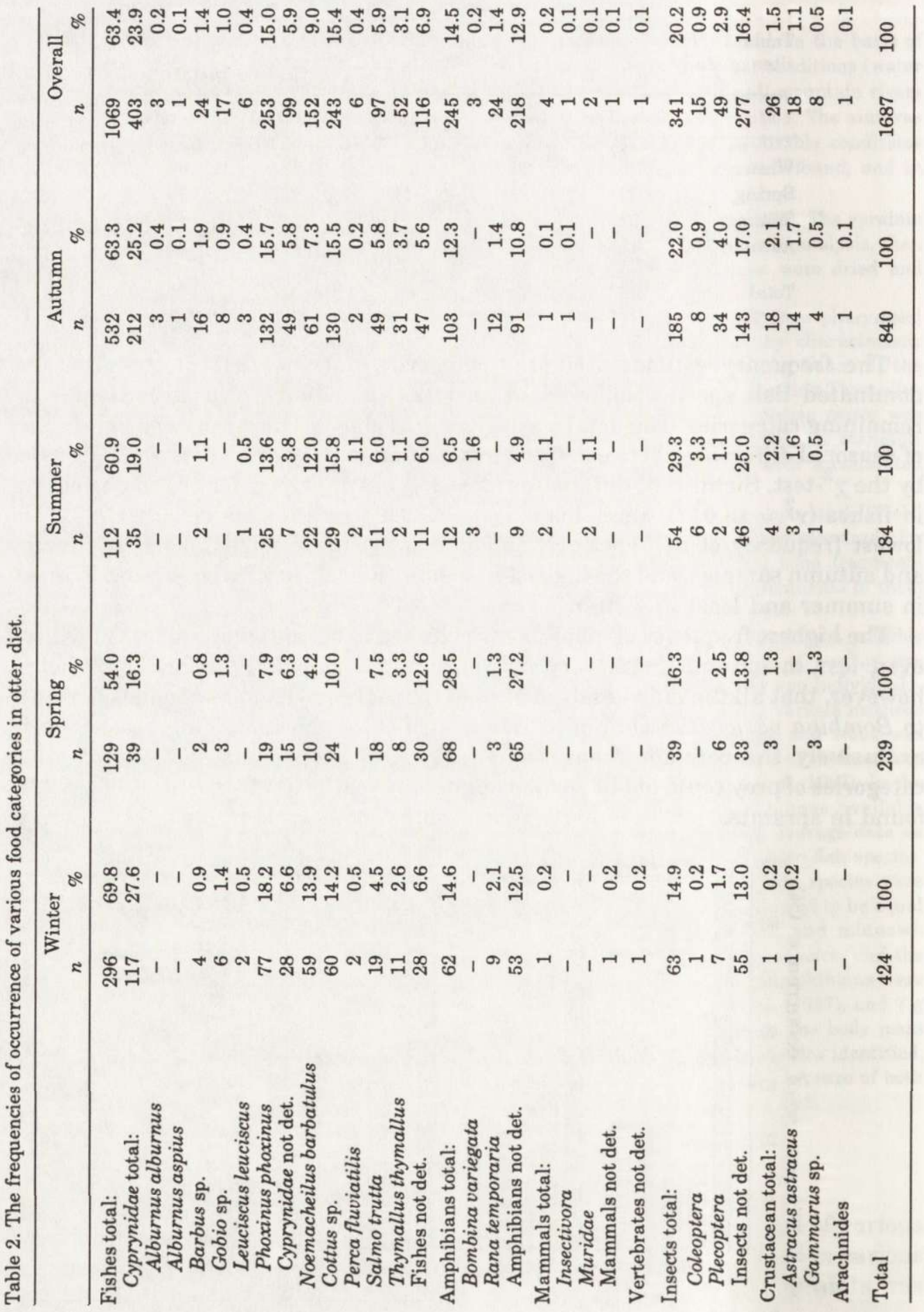




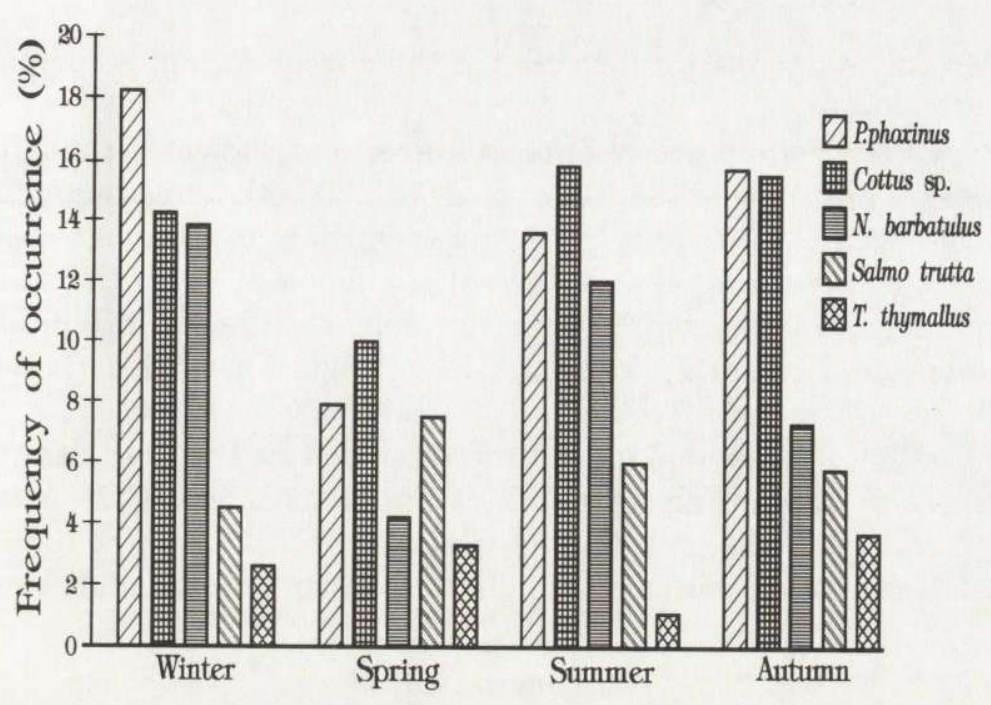

Fig. 2. Seasonal occurrences of important fish species in the otter diet.

Table 3. The percentage of biomass composition of otter diet in Bieszczady Mts.

\begin{tabular}{lccccc}
\hline & $\begin{array}{c}\text { Winter } \\
(\%)\end{array}$ & $\begin{array}{c}\text { Spring } \\
(\%)\end{array}$ & $\begin{array}{c}\text { Summer } \\
(\%)\end{array}$ & $\begin{array}{c}\text { Autumn } \\
(\%)\end{array}$ & $\begin{array}{c}\text { General } \\
(\%)\end{array}$ \\
\hline Fishes total: & 70.7 & 60.8 & 93.8 & 67.7 & 73.2 \\
Cyprynidae total: & 4.6 & 1.9 & 2.9 & 6.6 & 4.0 \\
$\quad$ Alburnus alburnus & - & - & - & 0.8 & 0.2 \\
Gobio sp. & 0.7 & 0.5 & - & 1.1 & 0.6 \\
Leuciscus leuciscus & 0.7 & - & 0.7 & 0.7 & 0.5 \\
Phoxinus phoxinus & 1.9 & 0.6 & 1.4 & 2.0 & 1.5 \\
Cyprynidae not det. & 1.3 & 0.8 & 0.8 & 2.1 & 1.2 \\
Noemacheilus barbatulus & 4.5 & 1.2 & 7.2 & 2.9 & 3.9 \\
Cottus sp. & 7.3 & 6.5 & 14.9 & 12.3 & 10.2 \\
Salmo trutta & 44.5 & 33.3 & 56.2 & 35.7 & 42.4 \\
Fishes not det. & 9.8 & 17.9 & 12.6 & 10.2 & 12.6 \\
Amphibians total: & 29.3 & 39.2 & 6.2 & 32.3 & 26.8 \\
Bombina variegata & - & - & 1.5 & - & 0.4 \\
Rana temporaria & 4.3 & 1.7 & - & 3.8 & 2.4 \\
Amphibians not det. & 25.1 & 37.5 & 4.6 & 28.6 & 23.9 \\
\hline
\end{tabular}

Among the various fish species (Fig. 2), the P. phoxinus was the most frequent in otter faeces ( $15 \%$ of all animals eaten). This species is the most common prey in winter and autumn. Cottus sp. was slightly less frequent (14.4\%). N. barbatulus was also frequent, particularly in winter and summer. S. trutta and T. thymallus 
did not show any significant differences in their frequency of occurrence in otter diet.

Percentage composition analysis of the otter diet indicates that in the study area fish species are the main source of food $(73.2 \%)$ with amphibians contributing markedly less $(26.8 \%)$. The proportions between these two components vary with the season: the lowest contribution of amphibians was found in summer (only $6.2 \%$ ), it increased rapidly to $32.2 \%$ in autumn, and $29.3 \%$ in winter, with the highest value found in spring at $39.2 \%$. The proportion of fish species changed accordingly.

Among the fish species making up the otter diet at the four sites, more than half was S. trutta accounting for $42.2 \%$ of the biomass of all the animals eaten (Table 3). Cottus $s p$. is second (10.2\%), and N. barbatulus third (3.9\%). The remaining fish species contributed negligible amounts to the overall diet composition.

\section{Discussion}

The lowest number of spraints found in summer and the highest in autumn and winter, agrees well with earlier findings (Conroy and French 1987, Macdonald and Mason 1987). Erlinge (1968) observed intensive marking with spraints between October and March when 2-year-old males trying to take over and mark their territories. Abundant vegetation in summer could also impede search for spraints and influence markedly the final numbers.

In the otter spraints collected, only two amphibian species were identified: the common frog and the yellow-bellied toad. The common frog occurred in the diet throughout the year except summer, while the yellow-bellied toad appeared in the diet only in summer.

The results of frequency analysis generally follow the data of other authors who also found that fishes are the most frequent victims of the otter (Erlinge 1969, Chanin 1981, Lopez-Nieves and Hernando 1984, Adrian and Moreno 1986, Adrian and Delibes 1987, Arcá and Prigonii 1987, Libois et al. 1987, Callejo 1988). Again the variability found in the Bieszczady Mts followed the pattern found by most of these authors. It is difficult to determine the cause of the variable frequency of various species of fish. The data do not suggest any relationship with spawning seasons.

To avoid mistakes, only ileum and frontoparietale bones were used to identify the remnants of amphibians down to the species. Even these bones were seldom found in the condition good enough to warrant positive identification, hence so many individuals were only warrant positive identification, hence so many individuals were only identified as "amphibians" without further identification of the species. Certain information could be drawn from the size of amphibian skeletons - in summer these were smaller animals. This seems to support the earlier assumption (applied to the cases of identified remnants) that all the amphibians eaten by otters in summer were yellow-bellied toads, while those found 
outside this seasons were common frogs. It is, nevertheless, a major simplification and might be a source of considerable errors.

If such an assumption is adopted, the changes in the frequencies of amphibians in the diet can easily be related to the reproductive seasons of these two species (the common frog reproduces in spring, the yellow-bellied toad - in summer) and with the manner of wintering (the edible common frogs come to waters and stay there throughout winter, becoming a potential prey to the otter, while the yellow-bellied toads winter on dry land and do not enter waters except in the reproduction season).

The per cent of biomass seems to be a better indicator of the relative imortance of various components in the diet. Estimates of this kind have been rather rare in the literature so far (Libois et al. 1987).

The estimate of biomass percentages presented in this work is of a preliminary nature due to the necessity to apply various methods to estimate biomass of various groups of animals found in the spraints. Several animal categories had to be dropped from this kind of analysis (cf methods), because of lack of relevant data.

There were great discrepancies in the estimates of frequency and biomass percentages for various animals in the diet of otters. The most striking differences appeared in the respect to the trout.. This can be explained by the fact that this species can reach much greater size than most of the fish species found in the diet, and finding even a limited number of such large individuals markedly affects the estimates of biomass percentage.

It could be expected that the estimates of frequency and biomass can be slightly exaggerated in cases of a large prey. The remnants of a large individual can be present in several samples which automatically increases the probability of finding it in the analysed material. To obtain an unabridged picture of the food preferences of the otter, and its role in various Bieszczady habitats, some more hydrobiological data are required which would help to more accurately determine the food supply for this species.

\section{References}

Adrian M. I. and Delibes M. 1987. Food habits of the otter Lutra lutra in two habitats of the Doñana National Park, SW Spain. J. Zool., Lond. 212: 399 - 406.

Adrian M. I. and Moreno S. 1986. Notas sombre la alimentacion de la nutria (Lutra lutra) en el embalse de Matavacas (Huelva). Acta Vertebr. 13: 189 - 191.

Arcá G. and Prigoni C. 1987. Food of the otter on the Fiora River (Central Italy). Acta theriol. 32: $134-140$.

Callejo A. 1988. Le chois des proies par la loutre Lutra lutra dans le nord-ouest l'Espagne, en rapport evec les facteurs de l'enviaronnement. Mammalia 52: $11-20$.

Camby A., Le Gall O. and Maizeret C. 1984. Atlas d'identification des restes alimentaires de la loutre (premier elements). Groupe Loutres, Bulletin de Liaison 16: 1-30.

Chanin P. 1981. The diet of the otter and its relations with the feral mink in two areas of southwest England. Acta theriol. 26: $83-95$. 
Conroy J. W. H. and French D. D. 1987. The use of spraints to monitor populations of otters (Lutra lutra). Symp. Zool. Soc. Lond. 58: $247-262$.

Erlinge S. 1968. Territoriality of the otter (Lutra lutra L.). Oikos 19: $81-98$.

Erlinge S. 1969. Food habits of the otter Lutra lutra and the mink Mustela vison in a trout water in southern Sweden. Oikos 20: $1-7$.

Goryczko K. 1986. Lipień [In: Ryby słodkowodne Polski. M. Brylińska, ed]. PWN - Polish Sci. Publ., Warsaw: $165-168$.

Günther R. 1985. Ordung Anura [In: Lurche und Krichtiere Europas. W. Engelmann, J. Fritzche, R. Günther and F. J. Obst, eds]. Neumann Verlag, Leipzig: 113 - 184.

Hallet-Libois K. 1984. Modulations de la strategie alimentaire d'un predateur: Eco-ethologie de la predation du martin-pecheur, Alcedo atthis (L. 1758), en periode de reproduction. $\mathrm{Ph}$. D. thesis Facultes Universitaires Notre-Dame de la Paix-Namur: 1 - 169.

Horoszewicz I. 1960. Wartoșc kosci gardłowych dolnych jako kryteri6́w gatunkowego oznaczania ryb karpiowatych. Roczniki Nauk Roln. Ser. B 75: 238 - 256.

Juszczyk W. 1974. Płazy i gady krajowe. PWN - Polish Sci. Publ., Warsaw: 1 - 722.

Kowalski K., Pucek Z. and Ruprecht A. L. 1984. Gryzonie - Rodentia [In: Klucz do oznaczania ssak6w Polski. Z. Pucek, ed]. PWN - Polish Sci. Publ., Warsaw: 149 - 240.

Libois R. M., Hallet-Libois C. and Lafontaine L. 1987. Le regime de la loutre Lutra lutra en bretagne interieure. Rev. Ecol. 42: 135 - 144.

Libois R. M., Hallet-Libois C. and Rosoux R. 1987. Elements pour l'identification des restes craniens des poissons dulcaquicoles de Belgique et du nord de la France. Centre de recherches Archeologiques du CNRS. APDCA. Juan-les-Pins: $1-15$.

Lopez-Nieves P. and Hernando J. A. 1984. Food habits of the otter in the Central Sierra Morena (Cordoba, Spain). Acta theriol. 29: $383-401$.

Macdonald S. M. and Mason C. F. 1987. Seasonal marking in an otter population. Acta theriol. 32: $449-462$.

Mann R. H. K. and Beaumont W. R. C. 1980. The collection, identification and reconstruction of lengths of fish prey from their remains in pike stomachs. Fish. Mgmt 11: 169-172.

Pielowski Z. 1980. Die Situation des Fischotters in Polen [In: Der Fischotter in Europa. C. Reuter and A. Festetics, eds]. Oderhaus und Gottingen: $183-185$.

Rolik H. and Rembiszewski J. M. 1987. Ryby i kragłoustne. PWN - Polish Sci. Publ., Warsaw: 1- 314.

Sikora S. 1984. Występowanie wydry Lutra lutra w Polsce. Pr. Komisji Nauk roln. i Komisji Nauk leśn., Poznań, Tow. Przyj. Nauk 57: 253 - 268.

Webb J. B. 1976. Otter spraint analysis. An occasional publication of the Mammal Society, Reading: $1-13$.

Wise M. H. 1980. The use of fish vertebrae in scats for estimating prey size of otters and mink. J. Zool., Lond. 192: 25 - 31.

Received 3 February 1992, accepted 28 February 1993. 